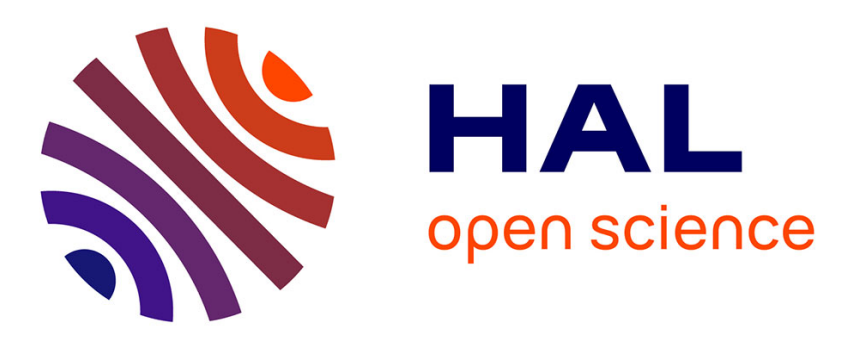

\title{
IS-LM and the multiplier: A dynamic general equilibrium model
}

\author{
Jean-Pascal Bénassy
}

\section{To cite this version:}

Jean-Pascal Bénassy. IS-LM and the multiplier: A dynamic general equilibrium model. 2006. halshs00590513

\section{HAL Id: halshs-00590513 \\ https://shs.hal.science/halshs-00590513}

Preprint submitted on 3 May 2011

HAL is a multi-disciplinary open access archive for the deposit and dissemination of scientific research documents, whether they are published or not. The documents may come from teaching and research institutions in France or abroad, or from public or private research centers.
L'archive ouverte pluridisciplinaire HAL, est destinée au dépôt et à la diffusion de documents scientifiques de niveau recherche, publiés ou non, émanant des établissements d'enseignement et de recherche français ou étrangers, des laboratoires publics ou privés. 
PARIS

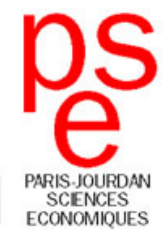

PARIS-Jourdan ScIEnCES ECONOMIQUeS

48, BD JOURDAN - E.N.S. - 75014 PARIS

TEL. : 33(0) 143136300 - FAX : 33 (0) 143136310

www.pse.ens.fr

WORKING PAPER Nº 2006 - 14

IS-LM and the multiplier:

A dynamic general equilibrium model

Jean-Pascal Bénassy

JEL Codes : E12, E62, E63

Keywords : IS-LM, DSGE models, Keynesian multiplier, crowding out, non-Ricardian economies. 


\title{
IS-LM and the Multiplier: A Dynamic General Equilibrium Model
}

\author{
Jean-Pascal Bénassy* \\ October 2005 \\ Revised February 2006
}

\begin{abstract}
We construct in this paper a dynamic general equilibrium model which displays the central features of the IS-LM model, and notably an income multiplier greater than one, so that crowding out does not occur. It appears that the key to this result is the conjunction of two features of our model: price rigidities (as is usually expected), but also a non-Ricardian economy.
\end{abstract}

*Address: CEPREMAP-ENS, 48 Boulevard Jourdan, Bâtiment E, 75014, Paris, France. Telephone: 33-1-43136338. Fax: 33-1-43136232. E-mail: benassy@pse.ens.fr 


\section{Introduction}

If one looks at the history of macroeconomics, one sees that two paradigms have dominated the profession. First, until the early seventies, the IS-LM model (Keynes, 1936, Hicks, 1937), then the dynamic stochastic general equilibrium (DSGE) paradigm (Lucas, 1972, Kydland and Prescott, 1982).

For a time many people believed that these two paradigms were totally irreconcilable, notably due to the fact that the early DSGE models, then called "real business cycles" (Long and Plosser, 1983), assumed full market clearing, whereas a central feature of IS-LM models was wage and price rigidities.

At some point, however, wage and price rigidities were introduced into DSGE models, which narrowed the gap between the two paradigms. Some authors further constructed DSGE models displaying some features of the IS-LM model (see for example McCallum and Nelson, 1999).

The integration is not yet complete, however, as some important features of the IS-LM model have not made fully their way into DSGE models. For example one of the most emblematic features of IS-LM, an income multiplier greater than 1, has been difficult to obtain in DSGE models as there is usually crowding out of consumption by government spending (see for example Fatas and Mihov, 2001, and Collard and Dellas, 2005).

So the purpose of this paper in to construct a DSGE model which will display the central features of the IS-LM model, and notably will allow to obtain a multiplier larger than one.

\section{The model}

It has been shown in Bénassy (2005) that in order to obtain sizeable multiplier effects it was important not only to have price or wage rigidities, but also to consider non Ricardian economies. By non Ricardian economies we mean, as in Barro (1974), economies where, due for example to the birth of new agents over time, Ricardian equivalence does not hold.

\subsection{An OLG economy}

So we shall consider a particularly simple non Ricardian economy, a monetary overlapping generations economy à la Samuelson (1958). In each period $t$ three markets are open: the goods market at price $P_{t}$, the labor market at the wage $W_{t}$ and the bonds market at the interest rate $i_{t}$. The private sector consists of firms and households. 


\subsection{The agents}

The representative firm in period $t$ has a production function:

$$
Y_{t}=Z_{t} L_{t}
$$

where $L_{t}$ is employment and $Z_{t}$ a productivity shock.

Households live for two periods. Households born in period $t$ work $L_{t}$, consume $C_{1 t}$ and hold a quantity of money $M_{1 t}$ in period $t$. In period $t+1$ they consume $C_{2 t+1}$ and hold a quantity of money $M_{2 t+1}$. They maximize the expected value of their utility $U_{t}$ :

$$
U_{t}=\alpha \log V_{1 t}+(1-\alpha) \log V_{2 t+1}-\frac{L_{t}}{a}
$$

with:

$$
V_{i t}=V\left(C_{i t}, \frac{M_{i t}}{P_{t}}\right) \quad i=1,2
$$

where the function $V$ is homogeneous of degree one in its two arguments and $M_{i t}$ is money held at the end of the period. As an example we may have the following C.E.S. specification:

$$
V\left(C_{i t}, \frac{M_{i t}}{P_{t}}\right)=\left[C_{i t}^{(\sigma-1) / \sigma}+\left(\frac{M_{i t}}{\theta P_{t}}\right)^{(\sigma-1) / \sigma}\right]^{\sigma /(\sigma-1)}
$$

where $\sigma$ is the elasticity of substitution between consumption and money balances. Since we want to model the idea that money facilitates transactions, and is thus somehow "complementary" to consumption, we shall assume that $\sigma<1$. As an example we may note that for $\sigma=0$ we obtain:

$$
V\left(C_{i t}, \frac{M_{i t}}{P_{t}}\right)=\operatorname{Min}\left(C_{i t}, \frac{M_{i t}}{\theta P_{t}}\right)
$$

which gives rise to a demand for money $M_{i t}=\theta P_{t} C_{i t}$ very akin to the traditional "cash in advance" specification. For positive values of $\sigma$ the demand for money will be sensitive to the interest rate, as we shall see below.

\subsection{Government policy}

The government uses monetary and fiscal policy. Monetary policy consists in choosing the interest rate $i_{t}$ on the bonds market. We may note that, although the interest rate is the policy tool, it may be manipulated so as to stabilize a monetary aggregate, such as the quantity of money. 
The second tool, fiscal policy, consists in choosing a level of government spending $G_{t}$ and taxes $T_{t}$ in real terms. We shall assume that taxes are levied on the young households, proportionately to their total income ${ }^{1}$ at the rate $\tau_{t}$. The tax rate $\tau_{t}$ is chosen so as to yield a real amount of taxes $T_{t}$, so that we have:

$$
\tau_{t}\left(W_{t} L_{t}+\Pi_{t}\right)=\tau_{t} P_{t} Y_{t}=P_{t} T_{t}
$$

\subsection{Budget constraints}

The old household starts period $t$ with total financial assets $\Omega_{t}$. He spends $P_{t} C_{2 t}$, and splits the rest between bonds $B_{2 t}$ and money $M_{2 t}$ :

$$
M_{2 t}+B_{2 t}=\Omega_{t}-P_{t} C_{2 t}
$$

If he lived through another period his wealth next period would be:

$$
\left(1+i_{t}\right) B_{2 t}+M_{2 t}=\left(1+i_{t}\right)\left(\Omega_{t}-P_{t} C_{2 t}-\frac{i_{t}}{1+i_{t}} M_{2 t}\right)
$$

But since he is not going to be alive next period, he wants this wealth to be zero, so that his budget constraint is:

$$
P_{t} C_{2 t}+\frac{i_{t}}{1+i_{t}} M_{2 t}=\Omega_{t}
$$

Let us now consider the young household born in $t$. He starts life with no assets, but receives wage income $W_{t} L_{t}$, profit income $\Pi_{t}=P_{t} Y_{t}-W_{t} L_{t}$, both being taxed at the rate $\tau_{t}$. He also spends $P_{t} C_{1 t}$, so that the sum of money $M_{1 t}$ and bonds $B_{1 t}$ is:

$$
M_{1 t}+B_{1 t}=\left(1-\tau_{t}\right)\left(W_{t} L_{t}+\Pi_{t}\right)-P_{t} C_{1 t}
$$

And his financial holdings at the beginning of next period $\Omega_{t+1}$ will be:

$$
\begin{gathered}
\Omega_{t+1}=\left(1+i_{t}\right) B_{1 t}+M_{1 t} \\
=\left(1+i_{t}\right)\left[\left(1-\tau_{t}\right)\left(W_{t} L_{t}+\Pi_{t}\right)-P_{t} C_{1 t}-\frac{i_{t}}{1+i_{t}} M_{1 t}\right]
\end{gathered}
$$

\footnotetext{
${ }^{1}$ Proportional taxes are used because lump sum taxes create income effects on labor supply which make some equations look less "natural". But the central results are the same.
} 


\section{The demand for money and the LM curve}

Budget constraints and maximization programs become particularly easy to study if we use the intermediate variable "total spending" $S_{i t}$ defined as:

$$
S_{i t}=P_{t} C_{i t}+\frac{i_{t}}{1+i_{t}} M_{i t}
$$

The second term represents the value of interest foregone because of holding money instead of bonds. From the preceding budget constraints we see that the optimal choices of the households can be somehow broken in two: The choice of $S_{i t}(i=1,2)$ and the allocation of this "total spending" $S_{i t}$ between consumption and money. Let us start with this second problem: For a given value of $S_{i t}$ the household, whether young or old, will maximize the value of $V_{i t}$, i.e. he will solve the following problem:

$$
\begin{gathered}
\text { Maximize } V_{i t}=V\left(C_{i t}, \frac{M_{i t}}{P_{t}}\right) \quad \text { s.t. } \\
P_{t} C_{i t}+\frac{i_{t}}{1+i_{t}} M_{i t}=S_{i t}
\end{gathered}
$$

The first order conditions are:

$$
\frac{V_{2}}{V_{1}}=\frac{i_{t}}{1+i_{t}}
$$

where $V_{1}$ and $V_{2}$ are the first and second partial derivatives of the function $V$. In view of the homogeneity of degree one of the function $V$, equation (13) defines a "demand for money" for the agent, which has the following form:

$$
\frac{M_{i t}}{P_{t} C_{i t}}=\Phi\left(\frac{i_{t}}{1+i_{t}}\right) \quad \Phi^{\prime}<0
$$

As an example with the C.E.S. subutility function above (4) we obtain the following demand for money:

$$
\frac{M_{i t}}{P_{t} C_{i t}}=\theta\left(\frac{\theta i_{t}}{1+i_{t}}\right)^{-\sigma}
$$

Now we obtain the following relation between total spending and consumption:

$$
S_{i t}=P_{t} C_{i t}+\frac{i_{t}}{1+i_{t}} M_{i t}=\zeta_{t} P_{t} C_{i t}
$$

where $\zeta_{t}$ is defined as: 


$$
\zeta_{t}=1+\frac{i_{t}}{1+i_{t}} \Phi\left(\frac{i_{t}}{1+i_{t}}\right)>1
$$

Let us now move to the aggregate values:

$$
C_{t}=C_{1 t}+C_{2 t} \quad M_{t}=M_{1 t}+M_{2 t}
$$

Aggregating the above relation (14) for young and old ( $i=1$ and 2), we obtain the total demand for money:

$$
\frac{M_{t}}{P_{t} C_{t}}=\Phi\left(\frac{i_{t}}{1+i_{t}}\right) \quad \Phi^{\prime}<0
$$

In which, since $i_{t} /\left(1+i_{t}\right)$ is srictly increasing in $i_{t}$, we recognize a demand for money very close to the traditional LM curve.

\section{Walrasian equilibrium}

Let us start with the old households, who enter period $t$ with a financial wealth $\Omega_{t}$. Combining (9) and (16) we find the consumption of the old:

$$
C_{2 t}=\frac{\Omega_{t}}{\zeta_{t} P_{t}}
$$

The young household is subject to the intertemporal budget constraint (11), which, in view of (16), becomes:

$$
\Omega_{t+1}=\left(1-\tau_{t}\right)\left(W_{t} L_{t}+\Pi_{t}\right)-\zeta_{t} P_{t} C_{1 t}
$$

In the first period of his life the household maximizes the expectation of his utility (2) subject to the budget constraint (21). We may note, from (20), that $C_{2 t+1}$ is proportional to $\Omega_{t+1}$. So the young household will solve:

$$
\begin{gathered}
\text { Maximize } \alpha \log C_{1 t}+(1-\alpha) \log \Omega_{t+1}-\frac{L_{t}}{a} \quad \text { s.t. } \\
\Omega_{t+1}=\left(1-\tau_{t}\right)\left(W_{t} L_{t}+\Pi_{t}\right)-\zeta_{t} P_{t} C_{1 t}
\end{gathered}
$$

The first order conditions for this program yield:

$$
\begin{gathered}
\zeta_{t} P_{t} C_{1 t}=\alpha\left(1-\tau_{t}\right)\left(W_{t} L_{t}+\Pi_{t}\right)=\alpha\left(1-\tau_{t}\right) P_{t} Y_{t}=\alpha\left(P_{t} Y_{t}-P_{t} T_{t}\right) \\
W_{t}=\frac{P_{t} Y_{t}}{a}
\end{gathered}
$$


Turning now to firms, the real wage must be equal to marginal productivity:

$$
\frac{W_{t}}{P_{t}}=Z_{t}
$$

Finally the equation of equilibrium on the goods market is:

$$
Y_{t}=C_{t}+G_{t}=C_{1 t}+C_{2 t}+G_{t}
$$

Combining equations (20), (22), (23), (24) and (25) we find the values of Walrasian output, employment, consumption and price:

$$
\begin{gathered}
Y_{t}=a Z_{t} \quad L_{t}=a \\
C_{t}=a Z_{t}-G_{t} \\
P_{t}^{*}=\frac{\Omega_{t}}{\left(\zeta_{t}-\alpha\right) a Z_{t}-\zeta_{t} G_{t}+\alpha T_{t}}
\end{gathered}
$$

We note that an increase in government spending $G_{t}$ decreases $C_{t}$ by an equal amount (equation 27), the traditional "crowding out" effect.

\section{The IS-LM system}

Traditionally the IS-LM system is associated with price rigidities, wage rigidities, or both. So we shall look for equations that are valid in all these cases.

If wages are sticky equation (23) is not valid anymore. If prices are sticky equation (24) is not valid. But equations (20), (22) and (25) are valid in all circumstances. Combining them we obtain:

$$
Y_{t}=\frac{1}{\zeta_{t}-\alpha}\left(\frac{\Omega_{t}}{P_{t}}+\zeta_{t} G_{t}-\alpha T_{t}\right)
$$

which looks very much like an $I S$ curve. This has to be supplemented by the $L M$ curve, which we saw above (equation 19):

$$
\frac{M_{t}}{P_{t} C_{t}}=\Phi\left(\frac{i_{t}}{1+i_{t}}\right) \quad \Phi^{\prime}<0
$$

Equations (29) and (30) form a system that is highly similar to the $I S-$ $L M$ system. We shall now investigate whether, as $I S-L M$, this system can display a strong multiplier effect. 


\section{Preset prices and the multiplier}

We shall now introduce a traditional price rigidity, preset prices in the tradition of Gray (1976):

$$
\frac{1}{P_{t}}=E_{t-1} \frac{1}{P_{t}^{*}}
$$

We still have to specify how monetary policy is operated. There are two traditional polar ways, setting the interest rate or setting the money supply, and we study them in turn.

\subsection{Setting the interest rate}

We first assume that the government sets a given interest rate $\left(i_{t}=i\right)$, letting the quantity of money adjust endogenously. As a consequence $\zeta_{t}$ is constant and equal to $\zeta$, and the IS curve is rewritten:

$$
Y_{t}=\frac{1}{\zeta-\alpha}\left(\frac{\Omega_{t}}{P_{t}}+\zeta G_{t}-\alpha T_{t}\right)
$$

Combining (28), (31) and $\zeta_{t}=\zeta$ we find:

$$
\frac{1}{P_{t}}=E_{t-1} \frac{(\zeta-\alpha) a Z_{t}-\zeta G_{t}+\alpha T_{t}}{\Omega_{t}}
$$

Inserting this into (32) we obtain:

$$
Y_{t}=a E_{t-1} Z_{t}+\frac{\zeta}{\zeta-\alpha}\left(G_{t}-E_{t-1} G_{t}\right)-\frac{\alpha}{\zeta-\alpha}\left(T_{t}-E_{t-1} T_{t}\right)
$$

We see that the multiplier, $\zeta /(\zeta-\alpha)$, is always greater than 1 .

\subsection{Setting the money supply}

We now study how the analysis is modified when the government controls the money supply instead of the interest rate. Let us recall the two $I S-L M$ equations:

$$
\begin{gathered}
Y_{t}=\frac{1}{\zeta_{t}-\alpha}\left(\frac{\Omega_{t}}{P_{t}}+\zeta_{t} G_{t}-\alpha T_{t}\right) \\
\frac{M_{t}}{P_{t} C_{t}}=\Phi\left(j_{t}\right) \quad \Phi^{\prime}<0
\end{gathered}
$$

with: 


$$
\zeta_{t}=1+j_{t} \Phi\left(j_{t}\right) \quad j_{t}=\frac{i_{t}}{1+i_{t}}
$$

Since we are actually interested in the sign of the consumption response, let us rewrite, deducting $G_{t}$ from both sides, the $I S$ curve as:

$$
C_{t}=\frac{1}{\zeta_{t}-\alpha}\left(\frac{\Omega_{t}}{P_{t}}+\alpha G_{t}-\alpha T_{t}\right)
$$

Let us differentiate (36) and (38), calling $\phi$ the absolute value of the elasticity of $\Phi$ :

$$
\begin{gathered}
\frac{d C_{t}}{C_{t}}-\phi \frac{d j_{t}}{j_{t}}=0 \\
\frac{d C_{t}}{C_{t}}=\frac{\alpha d G_{t}}{\left(\zeta_{t}-\alpha\right) C_{t}}-\frac{d \zeta_{t}}{\zeta_{t}-\alpha}
\end{gathered}
$$

Now we have from (37):

$$
d \zeta_{t}=\Phi\left(j_{t}\right)(1-\phi) d j_{t}
$$

Combining (37), (39), (40) and (41) we obtain:

$$
\frac{d C_{t}}{d G_{t}}=\frac{\alpha \phi}{\phi(1-\alpha)+\left(\zeta_{t}-1\right)}
$$

We see that consumption is again an increasing function of $G_{t}$. The multiplier is an increasing function of $\phi$. In the limit case where $\phi=0$ (the "cash in advance" case), the consumption does not move in response to a government spending shock.

\section{$7 \quad$ Partial price flexibility}

Let us now assume that the current price is given by:

$$
\frac{1}{P_{t}}=\gamma E_{t-1} \frac{1}{P_{t}^{*}}+(1-\gamma) \frac{1}{P_{t}^{*}}
$$

For $\gamma=0$ the price is fully flexible, for $\gamma=1$ we obtain the "Gray contract" above. We shall study here the interest rate setting case. Combining (28) and (43) we find:

$$
\frac{1}{P_{t}}=(1-\gamma) \frac{(\zeta-\alpha) a Z_{t}-\zeta G_{t}+\alpha T_{t}}{\Omega_{t}}
$$




$$
+\gamma E_{t-1} \frac{(\zeta-\alpha) a Z_{t}-\zeta G_{t}+\alpha T_{t}}{\Omega_{t}}
$$

Inserting this into (32) we find:

$$
\begin{gathered}
Y_{t}=(1-\gamma) a Z_{t}+\gamma a E_{t-1} Z_{t} \\
+\frac{\gamma \zeta}{\zeta-\alpha}\left(G_{t}-E_{t-1} G_{t}\right)-\frac{\gamma \alpha}{\zeta-\alpha}\left(T_{t}-E_{t-1} T_{t}\right)
\end{gathered}
$$

We see that the multiplier is greater than 1 if:

$$
\alpha>\zeta(1-\gamma)
$$

As should be expected from traditional Keynesian analysis, price flexibility decreases the multiplier.

\section{Conclusion}

We saw in this article that by adequately combining price rigidities and a non Ricardian framework we could obtain an income multiplier greater than one, or in other words that an increase in government spending could lead to an increase in private consumption. This was done in a dynamic stochastic general equilibrium model with maximizing agents.

Although it can be greater than one, the multiplier is not always so, and using a rigorous model allowed to specify the range of parameters for which no crowding out occurs. We studied notably the degree of price rigidity, and whether monetary policy is implemented by controlling interest rates or the supply of money.

It is thus comforting to know that the two paradigms that dominated macroeconomics for so long are, after all, not contradictory. 


\section{References}

[1] Barro, Robert J. (1974), "Are government bonds net wealth?", Journal of Political Economy, vol. 82, pp 1095-1117.

[2] Bénassy, Jean-Pascal (2005), "Ricardian equivalence and the intertemporal Keynesian multiplier", PSE and CEPREMAP, Paris.

[3] Collard, Fabrice and Harris Dellas (2005), "Poole in the new Keynesian model", European Economic Review, vol. 49, pp 887-907.

[4] Fatas, Antonio and Ilian Mihov (2001), "The effects of fiscal policy on consumption and employment: theory and evidence", working paper, INSEAD.

[5] Gray, Jo-Anna (1976), "Wage indexation: a macroeconomic approach", Journal of Monetary Economics, vol. 2, pp 221-235.

[6] Haavelmo, Trygve (1945), "Multiplier effects of a balanced budget", Econometrica, vol. 11, pp 1-12.

[7] Hicks, John R. (1937), "Mr. Keynes and the "classics": a suggested interpretation", Econometrica, vol. 5, pp 147-159.

[8] Keynes, John Maynard (1936), The General Theory of Employment, Interest and Money. New York: Harcourt Brace.

[9] Kydland, Finn E. and Prescott, Edward (1982), "Time to build and aggregate fluctuations", Econometrica, vol. 50, pp 1345-1370.

[10] Long, John B. and Charles I. Plosser (1983), "Real business cycles", Journal of Political Economy, vol. 91, pp 39-69.

[11] Lucas, Robert E. Jr (1972), "Expectations and the neutrality of money", Journal of Economic Theory, vol. 4, pp 103-124.

[12] McCallum, Bennett T. and Edward Nelson (1999), "An optimizing ISLM specification for monetary policy and business cycle analysis", Journal of Money, Credit and Banking, vol. 31, pp 296-316.

[13] Samuelson, Paul A. (1958), "An exact consumption-loan model of interest with or without the social contrivance of money", Journal of Political Economy, vol. 66, pp 467-482. 